\title{
Determinants Bank Profitability: Empirical Evidence from Bangladesh Commercial Banks
}

\author{
Abdus Samad $^{1}$ \\ ${ }^{1}$ Department of Finance and Economics, Utah Valley University, Orem, USA \\ Correspondence: Abdus Samad, Ph.D., Associate Professor, Department of Finance and Economics, Utah Valley \\ University, 800 W University PKY, Orem, UT 84058, USA. Tel: 801-863-8368. E-mail: abdus.samad@uvu.edu
}

Received: June 7, 2015

Accepted: July 17, 2015

Online Published: July 19, 2015

doi:10.5430/ijfr.v6n3p173

URL: http://dx.doi.org/10.5430/ijfr.v6n3p173

\begin{abstract}
The paper empirically examines the impact of bank specific characteristics and macroeconomic variables in determining the banks' profitablity of Bangladesh banking industry with a panel data. A total of 42 Bangladesh commercial banks' financial reports were analyzed; and bank specific characteristics such as bank financial risk, bank operational efficiency, and bank sizes as well as macroeconomic variables such as economic growth are examined to estimate their impact of bank profits. Results indicate that bank specific factors such as loan-deposit ratio, loan-loss provision to total assets, equity capital to total assets, and operating expenses to total assets are significant factors. Bank sizes and macroeconomic variable show no impact on profits.
\end{abstract}

Keywords: bank profitability, profitability determinants, Bangladesh

\section{Introduction}

Born in 1971, Bangladesh witnessed a phenomenal growth in banking industry since the liberalization policy was introduced in 1980s. Before the liberalization policy, there were only four domestic banks (Sonali Bank, Pubali Bank, Rupali Bank, and Janta Bank) in Bangladesh and they were nationalized. There were only three foreign banks (Alam and Riyadha, 2003). However, there was no private bank. As a result, there was no competition in the banking industry of Bangladesh. The banking market was highly concentrated and dominated by four nationalized banks. The profitability of banks was highly unsatisfactory due to corruption.

Since the liberalization policy was introduced, domestic private banks started growing and foreign banks were entering into Bangladesh. There are now fifty two banks operating in Bangladesh including eight foreign banks and seven Islamic banks. Of them, forty three are commercial banks. The total profit of commercial banks was TK 227299 (Million) in 2010. The profit of Commercial banks shows mixed picture in 2012.

While the profits of many commercial banks increased, the profits of other banks declined. Among the private commercial banks, Islamic Bank Bangladesh Ltd made the highest growth in profit. Its profits went up TK 1,830 crore in 2012 from profits TK 1,470 crore in 2011. The second was the Prime bank. Its profits went up TK950 crore in 2012 from TK825 crore in2011. Profit of nine commercial banks declined during 2011-2012. (Daily Star, January 1, 2013)

While the profit of some commercial banks increased, the profits of other banks commercial declined, this poses questions what internal factors which are within the control of bank managements determine the profitability of commercial banks in Bangladesh. This paper is motivated to estimate the determinants of the profitability of Bangladesh commercial banks regressing bank specific (internal) factors such as bank financial risk, bank operational efficiency, and bank sizes as well as macroeconomic variables such as economic growth.

The review of bank literature, in Section II, shows that there is no study on the determinants of commercial bank profitability in Bangladesh except Islam (2010) and Samad (2009) However, Islam's study dealt with how the bank size impacted bank profitability. Samad (2009) and Samad and Hameeda (2010) tested the validity of the market structure conduct performance hypothesis.

The paper contributes to the banking literature, Bangladesh banking in particular. First, the paper applies the quantitative estimate in determining profitability factor/s using panel regression. Second, the paper identifies the 
most significant factors on the profitability of Bangladesh banking industry. Third, the findings of this provides useful guide to bank management.

The paper is organized as: A short survey of literature is outlined in Section II. Data and methodology are discussed in Section III. Section IV provides empirical results and conclusion.

\section{Survey of Literature}

The survey of the literature of bank profitability determinants is classified into three areas such bank internal factors, bank industry structure, and bank sizes.

Bank specific factors bank internal factors. The internal factors of bank play a great role in determining profitability of a bank. Banks' internal factors include bank's operational efficiency, bank's risk aversion (capital ratio), bank liquidity, and credit quality. They play a significant role in determining a bank profits. Abreu and Mendes (2002), Kosmidau et al (2005) and Flamini et al (2009) found that bank capital have positive impact on a bank profits. A well-capitalized bank is a risk averse and enhances public confidence, lower bankruptcy costs and lead to have a positive impact on profits. This finding is collaborated by and Voug and Hoi (2009). Molyneux and Thornton (1992) found that bank profitability measured in return on equity (ROE) was positively related to bank concentration, bank ownership, and some macroeconomic variables in 18 European countries during 1986-1989. On the other hand, Asthanasoglou et al (2006) found that bank capital was negatively related to profitability in South Eastern European regions whereas macroeconomic variables such as GDP and inflation had positive impact on profitability.

Ben Naceur and Omran (2008) studied MENA countries commercial banks during 1989-2005. They found that bank specific characteristics such as credit risk and bank capital had positive and significant impact on bank profitability. However, they found no evidence of impact of macroeconomic variables on bank profitability. Hefferman and Fu (2008) found that macroeconomic variable such as inflation had positive impact on bank profitability.

Samad (2008) examined two competing hypothesis - structure-conduct-performance (SCP) and efficiency hypothesis (EH) — in Bangladesh banking market and found validity for EH for bank profitability.

Sufiyan and Habibullah (2009) examined the determinants of the profitability of the Chinese banking sector during the post-reform period of 2000-2005 and found that liquidity, credit risk, and capitalization had positive impacts on the state owned commercial banks' (SOCBs) profitability, while the impact of cost was negative on profitability.

Camilleri (2005) examined the banking industry of Malta and found that bank size was positively related to profitability. Islam (2010) examined the impact of bank sizes (measured in total assets, total loans and total deposits) on bank profit performances using OLS and found that bank sizes and bank profitability were positively related in Bangladesh.

Employing 1999-2002 data, Samad (2008) tested structure-conduct performance hypothesis (SCPH) and efficiency hypothesis $(\mathrm{EH})$ and found the validity of $\mathrm{EH}$ in determining the profitability of Bangladesh banking industry. Using the same 1999-2001 data, Samad (2009) examined the SCPH, EH and three internal variables of bank such as capital reserves to total assets, loans to deposits and bank assets. He found that EH and bank internal factors are important determinants.

This present paper is different from my previous studies in several ways. . (i) The present paper employs panel data for the year 2009, 2010 and 2011 when the banks faced global financial crisis whereas my previous used cross-sectional data. (ii) The current research contains more number of banks (fifty one banks) whereas the previous studyvexamined forty one banks. (iii) The 2008 and 2009 study did not include macroeconomic variables whereas the present paper includes macroeconomics variables: GDP. (iv) Unlike the previous studies, the present paper incorporates: bank operational efficiency, bank financial risks, bank credit risk, bank size, and macroeconomic variable.

The review of literature shows that there is no study of bank specific and macroeconomic determinants of bank profitability in Bangladesh banking sector. The absence of such study deserves the undertaking of research in this field.

\section{Data, Variables, and Methodology}

\subsection{Data}

Data of all bank specific variables such as profits, assets, loans, and net interest margin are obtained from the Website of respective bank's annual report and the income statement for year 2009 and 2010. Data of 
macroeconomic variables such as inflation and per capita GDP are obtained from International Financial Statistics. All ratios are estimated by the author.

\subsection{Variables}

There are two types of variables: Dependent variable and a set of independent variables. They are as follows:

\subsubsection{Dependent Variable}

Bank profits are expressed in two ways: ROA (Return on assets) and ROE (Return on equity). This paper uses average return on assets (ROA) instead of ROE. According to Flamini et al (2009), ROA is a better proxy of profit because ROE does ignore financial leverage. Samad (2008) used ROA. ROA is the profits earned per dollar of assets/ profits as percentage of total assets.

\subsubsection{Independent Variables}

Independent variables are selected from (I) bank specific characteristics and (II) macroeconomic variables.

(I) Bank specific determinants are classified into four broad categories as:
A. Liquidity risk
B. Credit risk/credit quality
C. Bank operational efficiency
D. Capital Efficiency
E. Bank size

(II) Macroeconomic variables include:

(i) Economic growth

(ii) Inflation

(I). Bank-specific Determinants

They are classified into five categories as:

\section{A. Liquidity Risk/Characteristic}

Liquidity and profitability are a tug of war. When a bank holds more cash reserves in bank's vault, it is more liquid and safe to pay depositors' claim. However, bank's profitability is compromised. On the other hand, a bank's profitability is increased when the banks invest for long term loans. Bank becomes vulnerable if its resources are invested in long term loans. The bank cannot meet the large demand for cash and new loans. Liquidity risk is basically a bank's inability to meet the cash demand of its customers. The liquidity of a bank is measured in several ways as:

(i) LOANTA $=$ Total loans as a percentage of total assets. Loans are larger percentage of interest earning asset of a bank. Therefore, when the LOANTA ratio increases, a bank's profitability increases. On the other hand, a bank liquidity risk increases when LOANTA ratio increases. It is, thus, expected that $\partial \pi / \partial L O A N T A>0$

(iii) LOANDEP= Loan as a percentage of deposits. When a bank transforms a higher percentage of its deposit into loans, the bank is expected to earn more profits. Thus, the higher the LOANDEP ratio the higher the profitability of a bank and the higher the liquidity risk for the bank. The higher amount of loans against per dollar deposit increases bank liquidity risk. Therefore, it is expected that $\partial \pi / \partial L O A N D>0$

\section{B. $\quad$ Credit Risk/Credit Characteristic}

The poor quality of bank loan gives rise to credit risk. A bank credit risk arises when a bank borrowers is in default i.e. when he/she fails to pay the installment or the principal. A bank credit risk is measured as:

(i) LLPTA = Loan loss provision as a percentage of total assets. The higher the LLPTA ratio, the lower the profitability of bank. When more dollars are kept aside for loan losses, it reduces bank profits. It is, thus, expected that $\partial \pi / \partial L L P T A<0$.

(ii) NPLLOAN= Non-performance loan as a percentage of total loan. Although this is the best measure of credit risk for a bank, it is not used due to non-availability of nonperformance loan data.

\section{Operational efficiency}

There are a number of indexes for measuring the operational efficiency of a bank. This study has used the following: 
(i) NIMOPEX $=$ Net interest margin as a percentage of total operating expenses. The NIM is estimated by interest income minus interest expense. It is generally expected that an efficient bank has higher NIMOPEX than an inefficient bank. It is, thus, expected that $\partial \pi / \partial N I M>0$.

(ii) OPEXTA= Operating expense to total assets. It is expected when a bank has higher operating expense per dollar assets, the profitability of a bank declines. On the other hand, when the operating expenses are directed for loans recovery, loans defaults, and asset managements, it is quite possible that the higher the OPEXTA, the higher profitability of a bank. It is, thus, expected that $\frac{\partial \pi}{\partial O P E X T A}<$ or $>0$.

\section{Capital Efficiency}

Bank's capital averse is measured by EQTA = represents bank' risk aversion index. It is measured by bank's equity capital as the percentage of total assets. The conventional risk-return hypothesis suggests negative relation between bank capital and bank profits. That is, the higher the amount of equity capital to total assets, the higher the risk aversion of a bank. The higher risk aversion implies low leverage and thus, low profits. So, it is expected, $\frac{\partial \pi}{\partial E Q T A}>0$.

\section{E. Bank size}

There are a number of indexes for measuring a bank size found in the banking literature. They are: (i) Total asset, (ii) Total deposits, and (iii) total loans. A large bank measured by either total assets or total loans or total deposits may either enjoy economies or diseconomies of scale. When a bank operates under economies of scale, it is expected that $\partial \pi / \partial \log T A=\partial \pi / \partial \log D e p=\partial \pi / \partial \log \operatorname{Loan}>0$, otherwise, $\partial \pi / \partial \log T A=\partial \pi / \partial \log D e p=\partial \pi / \partial \log \operatorname{Loan}<0$. Thus, the sign for the relationship between a bank size and profitability cannot be apriority determined.

\section{(II). Macroeconomic Determinants}

Economic growth affects bank profitability. The growth of economy demands more loans be financed. When more loans are financed by bank, bank profitability is expected to increase. Thus, economic growth and bank profitability is expected to show a positive relationship. Log GDP or per capita GDP is used for economic growth.

$$
\partial \pi / \partial G D P>0
$$

Inflation affects most economic variables, interest rate in particular. CPI is used to measure inflation. The higher the inflation rate, the higher interest rate. The higher interest rate increase banks' profitability. Thus bank profitability and inflation are positively related, $\partial \pi / \partial P>0$.

The descriptive statistics of dependent and all independent variables are presented in Table 1.

\begin{tabular}{llllll}
\hline Variable & Obs & Mean & Std. Dev. & Min & Max \\
\hline ROA & 40 & .0128111 & .0218233 & -.1085341 & .0412603 \\
LoanTA & 39 & .6578043 & .0999303 & .456931 & .8595706 \\
LoanDep & 39 & .847703 & .2943887 & .5697385 & 2.507014 \\
LLPTA & 40 & .0098293 & .0243288 & 0 & .1579111 \\
OPEXTA & 40 & .021698 & .0067225 & .0093529 & .0404405 \\
\hline NIMOPEX & 40 & 1.285446 & .6672954 & .1302679 & 4.614237 \\
EQTA & 40 & .0732407 & .0603851 & -.2336401 & .1711795 \\
EQTA & 40 & .0732407 & .0603851 & -.2336401 & .1711795 \\
$\operatorname{logTA}$ & 40 & 25.16887 & 1.007463 & 22.87768 & 27.57578 \\
$\operatorname{logDep}$ & 40 & 24.93539 & 1.064183 & 21.80726 & 27.3129 \\
\hline $\log$ GDP & 41 & 28.85538 & $3.60 \mathrm{e}-15$ & 28.85538 & 28.85538 \\
\hline CPI & 41 & 5.42 & 0 & 5.42 & 5.42 \\
\hline
\end{tabular}




\subsection{Methodology}

Panel Ordinary least square (OLS) is applied for estimating the impact of bank-specific characteristics and macroeconomic variables on bank profitability. The paper estimates the following linear OLS model in the form:

$$
\Pi_{i t}=\beta_{0}+\beta_{j t} \mathrm{X}_{j t}+\epsilon_{j t}
$$

Where $\pi$ = profit (ROA), $j$ refers to individual bank, $t$ refers to year, $X_{j}=$ set of independent bank-specific and macroeconomic variables discussed above in this section, and $\beta_{\mathrm{j}}=$ set of unknown parameters to be estimated. $\epsilon_{j t}$ is the random error term and is assumed to be normally distributed.

Before applying OLS, variables are tested for their correlation. Results for the correlation test are provided in Table 2.

Table 2. Results of correlation test for variables

\begin{tabular}{llllllll}
\hline & LoanTA & LoanDep & LLPTA & NIMOPEX & OPEXTA & EQTA & $\log A$ \\
\hline LoanTA & 1.0000 & & & & & & \\
LoanDep & $0.6285^{*}$ & 1.0000 & & & & & \\
LLPTA & 0.0559 & 0.0688 & 1.0000 & & & & \\
NIMOPEX & 0.3960 & $0.7679^{*}$ & -0.1320 & 1.0000 & & & \\
OPEXTA & -0.3770 & -0.3099 & 0.0832 & $-0.4727^{*}$ & 1.0000 & & \\
EQTA & 0.0357 & 0.2058 & -0.7171 & 0.3506 & -0.1678 & 1.0000 & \\
$\operatorname{logTA}$ & $-0.5421^{*}$ & -0.5180 & -0.2362 & -0.2892 & 0.3251 & 0.0040 & 1.0000 \\
$\operatorname{logDep}$ & $-0.5340^{*}$ & $-0.6108^{*}$ & -0.2391 & -0.3670 & 0.3197 & -0.0281 & $0.9909^{*}$ \\
$\operatorname{logGDP}$ & 0.1193 & 0.0788 & -0.0493 & 0.0064 & 0.0856 & 0.1054 & 0.1126 \\
CPI & 0.1193 & 0.0788 & -0.0493 & 0.0064 & 0.0856 & 0.1054 & 0.1126 \\
& 0.2920 & 0.4870 & 0.6622 & 0.9555 & 0.4472 & 0.3490 & 0.3169 \\
\hline & $\operatorname{logDep}$ & $\operatorname{logGDP}$ & CPI & & & & \\
\hline $\operatorname{logDep}$ & 1.0000 & & & & & & \\
$\operatorname{logGDP}$ & 0.0978 & 1.0000 & & & & & \\
CPI & 0.0978 & $1.0000^{*}$ & 1.0000 & & & & \\
\hline
\end{tabular}

$*=$ significant at a level of $5 \%$ or less.

Table 2 shows strong correlation among variables CPI and GDP (1.00) bank size variables: $\log$ TA and $\log$ Dep (0.99), liquidity variables: loanTA and loanDep (0.62), and efficiency variables: OpexTA and NIMOprex (0.47) and they are significant. Thus, the paper excludes one of the variables from each of the four categories and considers to use LoanDep, LLPTA, OPEXTA, $\log$ Dep, $\log$ GDP, and EQTA. They are also further tested for their correlation, if any. The result of the correlation of selected variable is reported in Table 3.

Table 3. Correlation among the selected variables

\begin{tabular}{lllllll}
\hline & LoanDep & LLPTA & EQTA & OPEXTA & $\operatorname{logDep}$ & $\operatorname{logGDP}$ \\
\hline LoanDep & 1.0000 & & & & & \\
\hline LLPTA & 0.1159 & 1.0000 & & & & \\
\hline EQTA & -0.0121 & -0.6131 & 1.0000 & & & \\
\hline OPEXTA & -0.2723 & 0.0579 & -0.1205 & 1.0000 & & \\
\hline $\operatorname{logDep}$ & -0.5260 & -0.2526 & 0.0471 & 0.3922 & 1.0000 \\
\hline
\end{tabular}


Table 3 show that there is no significant correlation among the variables and thus, they are employed for panel regression.

This paper estimates the following model and reports the result in Section 4:

$$
\text { ROA }=\beta_{0}+\beta_{1} \text { LoanDep }+\beta_{2} \text { LLPTA }+\beta_{3} \text { EQTA }+\beta_{4} \text { OPEXTA }+\beta_{5} \operatorname{logTA}+\beta_{6} \operatorname{logGDP}+\varepsilon
$$

\section{Empirical Results}

The results of panel regression are reported in Table 4.

Table 4. Results of Panel Regression for 2009-2011

\begin{tabular}{|c|c|c|c|c|c|c|}
\hline Random-effects GLS regression & & & & & & Number of obs $=80$ \\
\hline Group variable: Bank & & & & & & Number of groups $=41$ \\
\hline R-sq: within $=0.4105$ & & & & & & Obs per group: $\min =1$ \\
\hline between $=0.7763$ & & & & & & avg $=2.0$ \\
\hline \multirow[t]{2}{*}{ overall $=0.7485$} & & & & & & $\max =2$ \\
\hline & & & & & & Wald chi2 $(6)=139.73$ \\
\hline corr $\left(\mathrm{u} \_\mathrm{i}, \mathrm{X}\right)=0$ (assumed) & & & & & & Prob $>$ chi $2=0.0000$ \\
\hline ROA & Coef. & Std. Err. & $\mathrm{z}$ & $\mathrm{P}>|\mathrm{z}|$ & {$[95 \% \mathrm{Co}$} & nf. Interval] \\
\hline LoanDep & .0196297 & .0072714 & 2.70 & 0.007 & .005378 & .0338814 \\
\hline LLPTA & -.5641292 & .0749554 & -7.53 & 0.000 & -.711039 & -.4172194 \\
\hline EQTA & .1027102 & .0222641 & 4.61 & 0.000 & .0590734 & .146347 \\
\hline OPEXTA & .3282288 & .1996152 & 1.64 & 0.100 & -.0630098 & .7194675 \\
\hline logDep & .0017182 & .0020633 & 0.83 & 0.405 & -.0023258 & .0057623 \\
\hline $\log G D P$ & .0045583 & .0269979 & 0.17 & 0.866 & -.0483565 & .0574732 \\
\hline cons & -.187305 & .7604901 & -0.25 & 0.805 & -1.677838 & 1.303228 \\
\hline
\end{tabular}

Table 4 shows that the model has overall 74.85 explanatory power. The panel regression model explains 74.85 percent of the variation of profits (ROA) of Bangladesh banking industry by the six explanatory variables such as loan-deposit ratio (loanDeP), loan-loss provision to total assets (LLPTA), equity capital to total assets (EQTA), operating expenses to total assets (OPEXTA), deposits (logDep), and Macroeconomic variable, GDP $(\log$ GDP).

The Wald $\chi^{2}$ statistics 139.73 and its probability value (0.0000) suggests that the null-hypothesis of the slope of all coefficient, $\beta_{j t}=o$ is rejected. The slopes are significantly different than zero.

Table 4 also shows that the signs for the coefficient all the explanatory are consistent as explained by the model in Section 3.

Among the explanatory variables that have significant impact on the bank profitability of Bangladesh are the bank specific internal factors. They are loan-deposit ratio (loanDeP), loan-loss provision to total assets (LLPTA), equity capital to total assets (EQTA), and operating expenses to total assets (OPEXTA). The signs for the coefficient of these variables are consistent as expected in the model and are significant. The significance of these factors is supported by the low p-value, $\mathrm{P}>|\mathrm{z}|$. This results collaborates the findings of Sufiyan and Habibullah (2009) who found the profitability of the Chinese banking sector are significantly affected by liquidity, credit risk, and capitalization. The paper also lends support to the findings of Ben Naceur and Omran (2008) who studied MENA countries commercial banks during 1989-2005 and found that bank specific characteristics such as credit risk and bank capital had positive and significant impact on bank profitability.

The sign for macroeconomic factor, GDP, is positive (as expected in the model) but it not a significant factor for Bangladesh banking profitability.

Bank size measured by log deposit is not a significant factor although the sign for the coefficient is positive. 


\section{Conclusion}

The paper examines the profitability determinants of the forty three commercial banks of Bangladesh using regression model with panel data 2009-2011. The paper finds that bank specific (Internal) factors are important the bank profitability of Bangladesh. Among the bank internal factors, bank liquidity risk LoanDep (loan deposit ratio), credit risk (LLPTA), capital risk (EQTA), and bank efficiency (OPEXTA) are significant factors for determining the profitability of Bangladesh banking industry. The finding of this paper is consistent with the findings of Sufiyan and Habibullah (2009) and Ben Naceur and Omran (2008).

The paper has limitation. The most import limitation is that external variables such as inflation rate and market structure behavior are excluded in this study. They should be examined for the determinants of bank profitability for robust conclusions and policy prescriptions. A future research should include more bank internal factors as well as bank external factors in the determinants of bank profitability.

\section{References}

Abreu, M., \& Mendes, V. (2002). Commercial bank interest margin and profitability: Evidence from some EU countries. University of Porta Working paper series No. 112.

Asthanasoglou, P.P., Delis, M., \& Staitouras, C. (2006). Determinants of profitability in the South Eastern European Regions. Journal of Financial Decision Making, 2, 1-17.

Ben Naceur, S., \& Omran, M. (2008). The effects on bank regulation, competition, and financial reforms on MENA banks' profitability. Working Paper, Economic Research Forum.

Camilleri, S.J. (2005). An Analysis of the profitability, risk, and growth indicators of banks operating in Malta. Bank of Valletta Review, 31, 32-48.

Flamini, V., McDonald, C., \& Schumacher, L. (2009). Determinants of profitability in Sub-Shaharan Africa. IMF Working Paper NO 09/15, pp. 1-30. http://dx.doi.org/10.5089/9781451871623.001

Kosmidau, K., Tanna, S., \& Pasuours, F. (2005). Determinants of profitability of Domestic UK commercial banks: Panel Evidence from a period of 1995-2002. Money, Macro and Finance (IMF) Research Group Conference, September, 2009.

Molyneux, P., \& Thornton, J. (1992). Determinants of European bank profitability: A Note. Journal of Banking and Finance, 16, 1173-1178. http://dx.doi.org/10.1016/0378-4266(92)90065-8

Saleh Mohammed Mashehdul Islam. (2010). Banks’ Financial Performance and the Impact of Bank Size: Evidence from Bangladeshi Commercial Banks. Bank Parikrama, 35, 35-47.

Samad, A. (2008). Market Structure, Conduct and Performance: Evidence from the Bangladesh Banking Industry. Journal of Asian Economics, 19(2), 181-193. http://dx.doi.org/10.1016/j.asieco.2007.12.007

Samad, A., \& Hameeda Jasim. (2009). Determinants of Profit rate: External or Internal Factors? Evidence from Bangladesh Banking. Global Review of Business and Economic Research, 5(2), 175-184.

Simson, J. (2002). Impact of the internet banking: Observation and Evidence from developing and emerging markets. Telemarketing and Informatics, 19(4), 315-330. http://dx.doi.org/10.1016/S0736-5853(01)00019-3

Sufiyan, F., \& Habibullah, M.S. (2009). Bank Specific and Macroeconomic determinants of Bank profitability: Empirical Evidence from China Banking Sector. Frontier Economics in China, 4(2), 274-291. http://dx.doi.org/10.1007/s11459-009-0016-1

Voug, P.I., \& Hoi, S.C. (2009). Determinants of profitability in Macao. University of Macao Working Paper, July 2009. 